\title{
Ornithobacterium rhinotracheale infection in red wattled lapwings (Vanellus indicus) in Pakistan - a case report
}

\author{
Sajid Umar ${ }^{1}$, Mudassar Iqbal ${ }^{2 *}$, Abdul H. Khan², Aqsa Mushtaq ${ }^{3}$, \\ Kiran Aqil ${ }^{3}$, Tariq Jamil ${ }^{3}$, Sajjad Asif ${ }^{4}$, Nayab Qamar ${ }^{4}$, Asad Shahzad, \\ and Muhammad Younus ${ }^{6}$ \\ ${ }^{I}$ Department of Pathobiology, Faculty of Veterinary and Animal Sciences, PMAS Arid Agriculture University, \\ Rawalpindi, Pakistan \\ ${ }^{2}$ University College of Veterinary and Animal Sciences, The Islamia University of Bahawalpur, Pakistan \\ ${ }^{3}$ Veterinary Research Institute, Lahore, Pakistan \\ ${ }^{4}$ Department of Microbiology, University of Veterinary and Animal Sciences Lahore, Pakistan \\ ${ }^{5}$ Department of Pathology, University of Veterinary and Animal Sciences, Lahore, Pakistan \\ ${ }^{6}$ Department of Pathobiology, College of Veterinary and Animal Sciences, Jhang, Pakistan
}

UMAR, S., M. IQBAL, A. H. KHAN, A. MUSHTAQ, K. AQIL, T. JAMIL, S. ASIF, N. QAMAR, A. SHAHZAD, M. YOUNUS: Ornithobacterium rhinotracheale infection in red wattled lapwings (Vanellus indicus) in Pakistan - a case report. Vet. arhiv 87, 641-648, 2017.

\section{ABSTRACT}

Respiratory infections are of major concern in the poultry industry in Pakistan. Previously, wild birds have been reported to transmit respiratory infections. The Red Wattled Lapwing (RWL) is a wild bird prevalent in the Indus basin and the wetlands of Punjab, Pakistan. Out of total of eighteen RWL birds housed at Lahore Zoo, Pakistan, three birds died after showing signs of respiratory distress and paralysis, in August, 2014. Postmortem examination revealed air sacculitis and pneumonia. Microbiological examination revealed Ornithobacterium rhinotracheale (ORT) as the causative agent, which was later confirmed by Polymerase Chain Reaction (PCR). The isolate was found to be susceptible to amoxicillin, erythromycin, tetracycline and enrofloxacin, and resistant to gentamycin, neomycin and sulfamethoxazole/trimethoprim. All the remaining birds were treated with long acting tetracycline, and diseased birds eventually recovered. No further mortality was declared. This is the first report of its kind which demonstrates ORT infection in RWL in Punjab, Pakistan.

Key words: red wattled lapwings, Vanellus indicus, Ornithobacterium rhinotracheale, PCR, Pakistan

\footnotetext{
*Corresponding author:

Mudassar Iqbal, Lecturer, M. Phil, DVM, Department of Pathobiology, University College of Veterinary and Animal Sciences, The Islamia University of Bahawalpur, 63100, Bahawalpur, Pakistan, Phone: +92 629255 567; Fax: +92 62 9255 567; E-mail: mudassar.iqbal@iub.edu.pk
}

ISSN 0372-5480

Printed in Croatia 


\section{S. Umar et al.: Ornithobacterium rhinotracheale infection in lapwings}

\section{Introduction}

Respiratory infections are a major threat for both commercial and rural poultry in Pakistan, and lead to high economic losses. These infections could be of viral or bacterial origin e.g. avian influenza, newcastle disease, infectious bronchitis, infectious laryngotracheitis, mycoplasmosis, infectious coryza etc. (AHMAD et al., 2002; SULTANA et al., 2012). Wild birds have been found to transmit Newcastle Disease and Avian Influenza viruses, but other microbes may also be involved (PEARSON and McCANN, 1975; LI et al., 2004; CAUSEY and EDWARDS, 2008; HAFEZ and LIERZ, 2010; SAEED et al., 2012; SHABBIR et al., 2014). Ornithobacterium rhinotracheale (ORT) is a Gram negative bacterium that infects the respiratory tract, causes air sacculitis, pneumonia and mortality in domestic, as well as in wild birds (VAN EMPEL and HAFEZ, 1999; VAN VEEN, 2000; HAFEZ and LIERZ, 2010).

Pakistan has diverse habitats of wild birds, from the temperate forests of the Himalayas, to the plains of Punjab and the deserts of Baluchistan and Sindh (GRIMMETT et al., 2008). The Red-Wattled Lapwing (Vanellus indicus) (RWL) is a medium-sized bird of the Charadriidae family, and is endemic to the Indus basin and the open wetland areas of Punjab province (MAAN and CHAUDHRY, 2001; AKBAR et al., 2005; ALI and AKHTAR, 2005; IQBAL et al., 2007; UMAR et al., 2016). ORT infection has already been reported in domestic birds in Pakistan (NAEEM et al., 2003; SIDDIQUE et al., 2008). However, this is the first report of its kind in wild birds in Pakistan, i.e. the RWL, based on isolation and molecular identification of the agent.

\section{Materials and methods}

Case history and necropsy examination. The previous history revealed that during August 2014 a total of eighteen adult RWL birds were captured from the wetlands of Kasur district (the adjoining district to Lahore, Pakistan) and moved to Lahore Zoo, Lahore. After one month, the birds started showing signs of lethargy, swollen head, purulent nasal discharge and paralysis. Despite routine antibiotic therapy, mortality occurred in three birds which were presented for post-mortem examination at the Veterinary Research Institute, Lahore, Pakistan. Post-mortem examination revealed haemorrhagic trachea, serofibrinous exudate in the lungs, air-sacculitis and splenomegaly. The organs were collected and processed for standard histopathological examination.

Microbiological examination. Virology. Heart blood, lungs, and air sacs were collected aseptically for microbiological evaluation. The tissue samples were homogenised in $10 \% \mathrm{w} / \mathrm{v}$ in sterile saline solution $(9.0 \mathrm{~g}$ of $\mathrm{NaCl}$ per liter (Sigma- Aldrich 3050 Spruce St., St. Louis, MO 63103, USA), added with 1 G Polybiotic (PDH-Pakistan) and centrifuged at $1000 \times g$ for 5 minutes. Supernatant $(0.2 \mathrm{~mL})$ was inoculated into 9 day old Specific Pathogen Free (SPF) chicken embryonated eggs and incubated at $37^{\circ} \mathrm{C}$. Allantoic fluid 


\section{S. Umar et al.: Ornithobacterium rhinotracheale infection in lapwings}

was harvested after $96 \mathrm{~h}$ post-inoculation, and subjected for Hemagglutination (HA) and Hemagglutination Inhibition tests (HI) against Newcastle Disease (ND) and Avian Influenza (AI) (ALEXANDER, 2000; OIE, 2009). The tests showed negative results for both ND and AI.

Bacteriology. Tissue swabs, enriched in Tryptic Soya broth, were streaked on 5\% sheep blood agar, MacConkey agar and pleuropneumonia like organism (PPLO) agar (Oxoid LTD, Basingstoke, Hampshire, England) for $48 \mathrm{~h}$ at $37^{\circ} \mathrm{C}$ as described previously (DUFOUR-ZAVALA et al., 2008; CHURRIA et al., 2011). Small, circular and non-haemolytic colonies were found on 5\% sheep blood agar, whereas there was no growth on MacConkey and PPLO agar. The biochemical identification was carried out using a commercial biochemical test kit (Bio-Me'rieux; Marcy l'Etoile, France). Gram's staining revealed Gram-negative pleomorphic bacilli. Biochemically, the isolate was found to be negative for catalase, positive for oxidase and Voges-Proskauer (VP) tests. The sugar fermentation test was positive for sucrose and maltose, but negative for sorbitol and dulcitol.

Histopathological investigations. Tissue specimens (Trachea, air sacs and lungs) were dissected and preserved in a $10 \%$ neutral buffered formalin solution. Varying concentrations of isopropyl alcohol $(70 \%, 80 \%, 90 \%, 96 \%$, and $100 \%)$ were used for the dehydration. The minimum time for dehydration between two different concentrations was $1 \mathrm{~h}$. The fixed tissues were then processed for routine histological examination. The sections $(5 \mu \mathrm{m})$ from each of the tissues were examined using a light microscope $(\times 40)$ after staining with hematoxylin and eosin dye (BANCROFT and GAMBLE, 2007).

Molecular identification. DNA extraction. The suspected isolate was subjected to genome extraction by phenol-chloroform method, with slight modifications (ThermoFisher Scientific, Carlsbad, CA) as described previously (ASADPOUR et al., 2008). Briefly, the colonies were vortexed in $500 \mu \mathrm{L}$ lysis buffer (Tris $\mathrm{HCl} 10 \mathrm{mM}+$ EDTA $1 \mathrm{mM}+1 \%$ $\mathrm{SDS}+200 \mu \mathrm{g} / \mathrm{mL}$ Proteinase $\mathrm{K}$ ) and heated at $56{ }^{\circ} \mathrm{C}$ in a water bath. An equal volume of phenol was added and centrifuged at $13000 \mathrm{rpm}$ for 15 minutes. The upper phase was taken out in a new tube, mixed with equal volumes of phenol-chloroform, and centrifuged. The upper phase was taken again in a new tube, mixed with an equal volume of chloroform, and centrifuged. The upper phase was taken out for the third time and mixed with twofold volume of $0.1 \%$ sodium acetate, and then an equal volume of $90 \%$ ethyl alcohol. It was incubated at $-20{ }^{\circ} \mathrm{C}$ for 20 minutes and centrifuged. The supernatant was discarded, $200 \mu \mathrm{L}$ of $70 \%$ ethyl alcohol was added and centrifuged. The alcohol was dried off by incubating in lid open tubes at $30^{\circ} \mathrm{C}$ for 10 minutes on blotting paper. A total of $100 \mu \mathrm{L}$ sterile, DNase free water was added to use as template DNA.

PCR amplification. Polymerase Chain Reaction (PCR) was used for molecular identification of the agent based on 16S rRNA fragment amplification, as described previously (HAFEZ, 2002; PAN et al., 2012). The forward and reverse primers used were 
5'-GAGAATTAATTTACGGATTAA-3' and 5'-TTCGCTTGGTCTCCGAAGAT-3' respectively. The PCR product (784 bp size) was analysed in $1.5 \% \mathrm{w} / \mathrm{v}$ agarose gel by electrophoresis (Fig. 1).

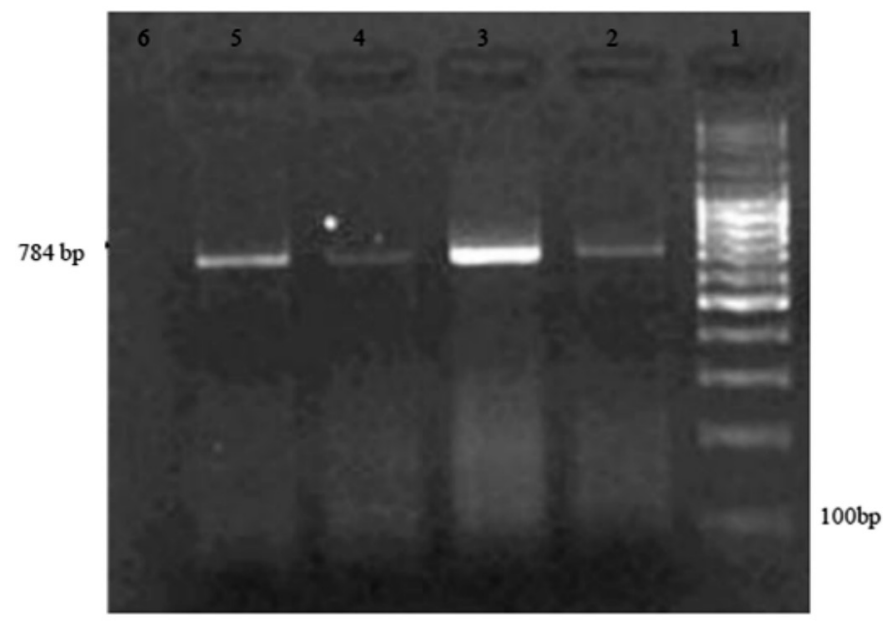

Fig. 1. PCR for Ornithobacterium rhinotracheale (784 bp). Lane 1, 100bp Marker; Lane 2, 3, 4:

ORT isolate; Lane 5: Positive control; Lane 6: Negative control.

Antimicrobial susceptibility test. In vitro antibiotic susceptibility was determined by the disk diffusion method, against seven commercially available antibiotics i.e. amoxicillin, erythromycin, tetracycline, enrofloxacin, gentamycin, neomycin, and sulfamethoxazole / trimethoprim (Oxoid LTD, Basingstoke, Hampshire, England) as described previously (BAUER et al., 1966).

\section{Results and discussion}

Respiratory problems are common in birds in Pakistan and lead to huge economic losses. A total of 18 birds were affected by respiratory illness, out of which $3(16.7 \%)$ birds died. The most common gross findings were tracheitis, unilateral pneumonia, and abdominal airsacculitis, with a foamy, white yogurt-like exudate, as described previously (HAFEZ, 2002; HAFEZ and LIERZ 2010; PAN et al., 2012; CHURRIA et al., 2012). Histopathological examination revealed acute fibrinous air sacculitis, oedema and congestion of the lungs. In the trachea a mild degree of deciliation and infiltration of inflammatory cells was revealed (Fig. 2). The severity of these lesions is usually influenced by environmental factors, such as housing, feeding and climate (CHURRIA et al., 2012). 

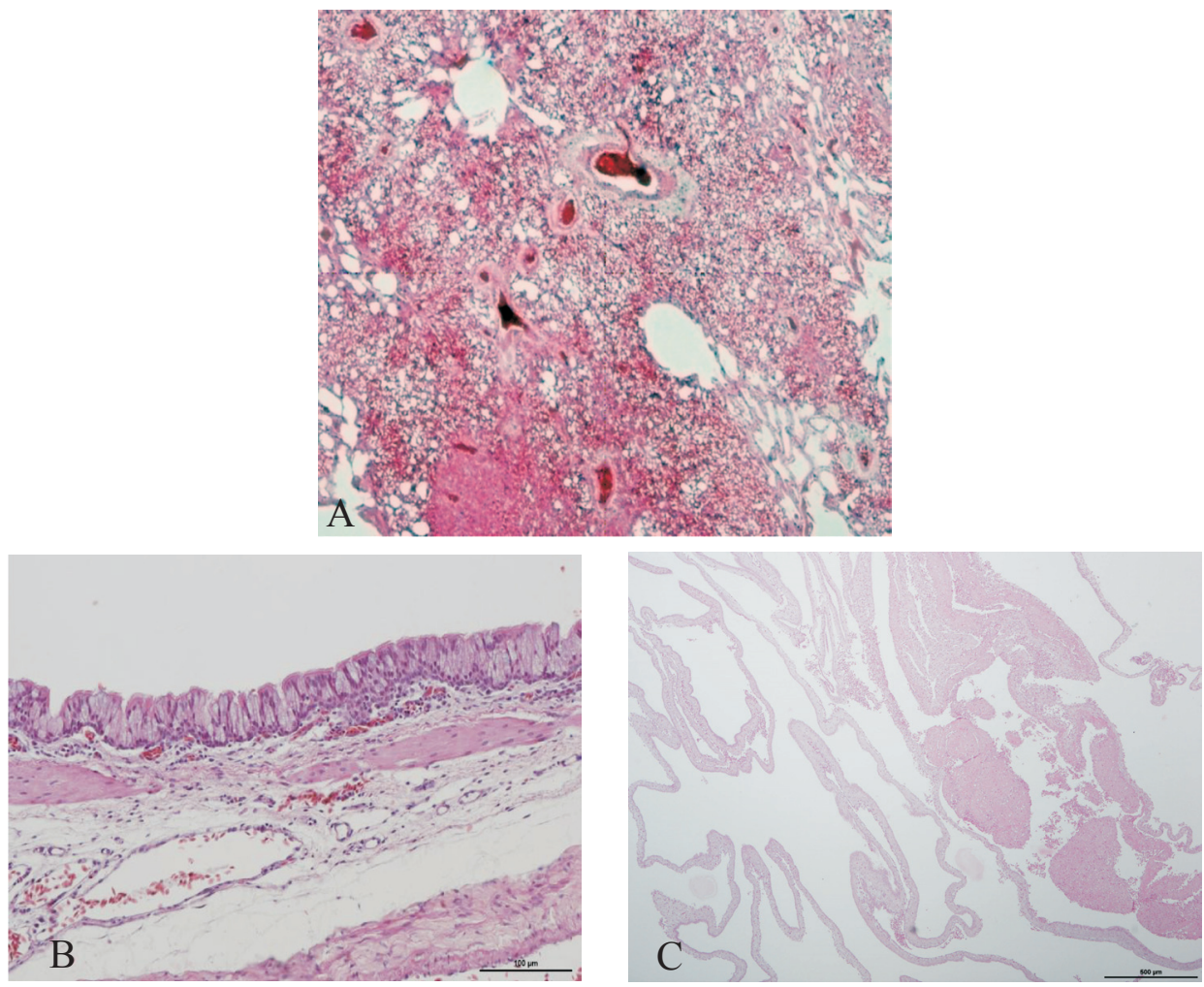

Fig. 2. Photomicrograph of lungs showing oedema and congestion (A) mild deciliation in trachea along with inflammatory cell infiltration (B) and fibrinous air sacculitis (C) in Red Wattled Lapwings

Bacteriological examination revealed ORT as the suspected aetiological agent, which was later confirmed by PCR amplification. This bacterium is difficult to isolate, especially in a contaminated environment, due to complex competition in-vitro, so it is likely to escape diagnosis (HAFEZ, 2002; SHABBIR et al., 2015). Previously, ORT infection has been described in commercial poultry in Pakistan (NAEEM et al., 2003; SIDDIQUE et al., 2008), however, this is the first report to describe it in wild birds.

The isolate was found susceptible to amoxicillin, erythromycin, tetracycline, and enrofloxacin, but resistant to gentamycin, neomycin, and sulfamethoxazole/trimethoprim. The results are consistent with previous studies where this bacterium was found to be susceptible to $\beta$-lactam antibiotics, tetracycline and chloramphenicol, and a lesser extent to neomycin and enrofloxacin (AK and TURAN, 2001; DEVRIESE et al., 2001; SIDDIQUE 
et al., 2008; ASADPOUR et al., 2008). Resistance to gentamycin has also been reported previously (VAN EMPEL and HAFEZ, 1999; SORIANO et al., 2003).

The remaining birds were treated with two shots of long-acting tetracycline (Rasomycin- LA, Star Laboratories Pvt LTD, Pakistan, $100 \mathrm{mg} / \mathrm{kg} \mathrm{IM}$ ) for treatment, with an interval of three days. Clinical signs abated later on and the birds started feed intake. No further mortality was reported.

\section{Conclusion}

On the basis of this study it may be said that ORT infection is present in wild birds in Pakistan and is treatable. The infection must be included in differential diagnosis of respiratory problems in birds. Further studies on isolation, characterization and pathogenicity are recommended for a better understanding of the agent.

\section{Conflicts of interest}

All authors declare no conflict of interest.

\section{References}

AHMAD, S. H. K., N. FAWAD, B. SIDDIQUE, H. REHMAN (2002): Current respiratory disease problem and the probes in chicken. Pak. Vet. J. 22, 17-20.

AK, S., N. TURAN (2001): Antimicrobial susceptibility of Ornithobacterium rhinotracheale isolated from broiler chickens in Turkey. Vet. arhiv 71, 121-127.

AKBAR, M., R. KHAN, S. MEHBOOB, Z. NISA (2005): Wildlife of border belt game reserve district Narowal, Punjab, Pakistan. Pak. J. Life. Soc. Sci. 3, 13-17.

ALEXANDER, D. J. (2000): Newcastle disease and other avian paramyxoviruses. Rev. Sci. Tech. $19,443-462$.

ALI, Z., M. AKHTAR (2005): Bird surveys at wetlands in Punjab, Pakistan, with special reference to the present status of White-headed Duck Oxyura leucocephala. Forktail. 21, 43-50.

ASADPOUR, Y., M. H. BOZORGMEHRIFARD, S. A. POURBAKHSH, M. BANANI, S. CHARKHKAR (2008): Isolation and identification of Ornithobacterium rhinotracheale in broiler breeder flocks of Guilan province, north of Iran. Pak. J. Biol. Sci. 11, 1487-1491.

BANCROFT, J. D., M. GAMBLE (2007). Theory and practice of histological techniques. Churchill Livingstone London, 5, 125-138.

BAUER, A. W., W. M. KIRBY, S. J. SHERRIS, M. TURCK (1966): Antibiotic susceptibility testing by a standardized single disk method. Am. J. Clin. Pathol. 45, 493-496.

CAUSEY, D., S, V. EDWARDS (2008): Ecology of avian influenza virus in birds. J. Infect. Dis. 197, 29-33.

CHURriA, C. D. G., M. A. MACHUCA, G. B VIGO, M. A. PETRUCCELli (2012): Ornithobacterium rhinotracheale infection in poultry: an updated review. Int. J. Mol. Zool. 2, 23-38. 
CHURRIA, C. D. G., P. L. SANSALONE, G. B. VIGO, G. H. SGUAZZA, M. A. MACHUCA, J. A. ORIGLIA, M. V. PÍSCOPO, M. A. H. LOYOLA, M. A. PETRUCCELLI (2011): Pneumonia in broiler chicken flocks associated with $\beta$-hemolytic Ornithobacterium rhinotracheale infection. Braz. J. Vet. Pathol. 4, 243-246.

DEVRIESE L. A., P. DE, HERDT, F. HAESEBROUCK (2001): Antibiotic sensitivity and resistance in Ornithobacterium rhinotracheale strains from Belgian broiler chickens. Avian Pathol. 30, 197-200.

DUFOUR-ZAVALA, L., D. E. SWAYNE, J. R. GLISSON, J. E. PEARSON, W. M. REED, M. W. JACKWOOD, P. R. WOOLCOCK (2008): A laboratory manual for the isolation, identification and characterization of avian pathogens. American Association of Avian Pathologists, USA. pp. 59-64.

GRIMMETT, R., T. J. ROBERTS, T. INSKIPP, C. BYERS (2008): Birds of Pakistan. A \& C Black, UK. pp. 6-247.

HAFEZ, H. M. (2002): Diagnosis of Ornithobacterium rhinotracheale. Int. J. Poult. Sci. 1, 114-118.

HAFEZ, H. M., M. LIERZ (2010): Ornithobacterium rhinotracheale in nestling falcons. Avian Dis. 5, 51-52.

IQBAL, M. Z., S. MALIK, A. A. CHAUDHRY, A. M. YOUSAFZAI, A. SHAKOORI, M. ZAHID, I. AHMAD, M. FATIMA, R. ABDUL, M. AFZAL (2007): Birds of Lahore cantonment. Pak. J. Zool. 39, 203-214.

LI, K. S., Y. GUAN, J. WANG, G. J. SMITH, K. M. XU, L. DUAN, A. P. RAHARDJO, P. PUTHAVATHANA, C. BURANATHAI, T. D. NGUYEN (2004): Genesis of a highly pathogenic and potentially pandemic H5N1 influenza virus in eastern Asia. Nature. 430, 209-213.

MAAN, M. A., A. A. CHAUDHRY (2001): Wildlife diversity in the Punjab (Pakistan). OnLine J. Biol. Sci.1, 417-420.

NAEEM, K., A. MALIK, A. ULLAH (2003): Seroprevalence of Ornithobacterium rhinotracheale in chickens in Pakistan. Vet. Rec. 153, 533-534.

OIE, (2009): Manual of diagnostic tests and vaccines for terrestrial animals (Mammals, Birds and Bees). pp. 576-589.

PAN, Q., A. LIU, F. ZHANG, Y. LING, C. OU, N. HOU, C. HE (2012): Co-infection of broilers with Ornithobacterium rhinotracheale and H9N2 avian influenza virus. BMC Vet. Res. 8: 104.

PEARSON, G. L., M. K. McCANN (1975): The role of indigenous wild, semidomestic, and exotic birds in the epizootiology of velogenic viscerotropic Newcastle disease in southern California, 1972-1973. J. Am. Vet. Med. Assoc. 167, 610-614.

SAEED, A., F. AFZAL, M. ARSHAD, S. HASSAN, M. ABUBAKAR (2012): Detection of Avian Influenza virus H5N1 serotype in backyard poultry, wild and zoo birds in Pakistan. Revue. Med. Vet. 163, 552-557. 


\section{S. Umar et al.: Ornithobacterium rhinotracheale infection in lapwings}

SHABBIR, M. Z., T. MALYS, Y. V. IVANOV, J. PARK, M. A. B. SHABBIR, M. RABBANI, T. YAQUB, E. T. HARVILL (2015): Microbial communities present in the lower respiratory tract of clinically healthy birds in Pakistan. Poult. Sci. 94, 612-620.

SHABBIR, M. Z., J. PARK, K. MUHAMMAD, M. RABBANI, M. Y. RANA, E. T. HARVILL (2014): Culture independent analysis of respiratory microbiome of Houbara bustard (Chlamydotis undulata) revealed organisms of public health significance. Int. J. Agri. Biol. $16,222-226$.

SIDDIQUE, M., T. ZIA, S. REHMAN (2008): Outbreak of Ornithobacterium rhinotracheale (ORT) infection in chickens in Pakistan. Archiv. Geflügelkunde 72, 202-206.

SORIANO, V., N. VERA, C. SALADO, R. FERNANDEZ, P. BLACKALL (2003): In vitro susceptibility of Ornithobacterium rhinotracheale to several antimicrobial drugs. Avian Dis. 47, 476-480.

SULTANA, R., B. SIDDIQUE, R. ALI, S. CHAUDHARY (2012): A study on the prevalence of respiratory diseases in broiler and layer flocks in and around Lahore district. Punjab Univ. J. Zool. 27, 13-17.

UMAR, S., K. AQIL, R. QAYYUM, M. YOUNUS, Q. NISA, S. ALI, M. A. SHAH, M. IRFAN, M. YAQOOB (2016): Haematology and Blood Chemistry references values for clinically healthy Red-wattled Lapwing (Vanellus indicus). European J. Wildlife Res. 62, 797-803 (in Chinese).

VAN EMPEL, P. C., H. M. HAFEZ (1999): Ornithobacterium rhinotracheale: a review. Avian Pathol. 28, 217-227.

VEEN, L. V (2000): Ornithobacterium rhinotracheale infections in poultry: a review. Tijdschr. Diergeneeskd. 125, 113-116 (in Dutch).

Received: 19 May 2016

Accepted: 17 September 2016

UMAR, S., M. IQBAL, A. H. KHAN, A. MUSHTAQ, K. AQIL, T. JAMIL, S. ASIF, N. QAMAR, A. SHAHZAD, M. YOUNUS: Infekcija vrstom Ornithobacterium rhinotracheale u crvenolikih vivaka (Vanellus indicus) u Pakistanu - prikaz slučaja. Vet. arhiv 87, 641-648, 2017.

\section{SAŽETAK}

Dišne infekcije od velike su važnosti za peradarsku industriju u Pakistanu. Znano je da ih mogu prenositi divlje ptice. Crvenoliki vivak nastanjuje bazen Indus i močvarna područja Pendžaba u Pakistanu. Od ukupno 18 crvenolikih vivaka iz Zoološkog vrta Lahore, tri su uginula nakon pojave znakova dišnog poremećaja i paralize u kolovozu 2014. Razudbom je utvrđen sacculitis i pneumonija. Mikrobiološkom pretragom dokazan je Ornithobacterium rhinotracheale što je bilo potvrđeno lančanom reakcijom polimerazom. Izolat je bio osjetljiv na amoksicilin, eritromicin, tetraciklin i enrofloksacin, a otporan na gentamicin, neomicin i sulfametoksazol/ trimetoprim. Sve preživjele ptice bile su liječene tetraciklinom s produženim djelovanjem i ozdravile. Novi slučajevi uginuća nisu bili primijećeni. Ovo je prvo izvješće o pojavi infekcije vrstom Ornithobacterium rhinotracheale u crvenolikog vivka u Pendžabu u Pakistanu.

Ključne riječi: crvenoliki vivak, Vanellus indicus, Ornithobacterium rhinotracheale, PCR, Pakistan 